\title{
Demographic Issues of Intra-European Migration: Destinations, Family and Settlement
}

\author{
Teresa Castro-Martín ${ }^{1} \cdot$ Clara Cortina $^{2}$
}

Published online: 31 March 2015

(C) Springer Science+Business Media Dordrecht 2015

The process of European integration has created a unique transnational space without internal borders. Citizens of the European Union are currently free to move to any of the 28 member states in search of work, education and career opportunities, for family reasons, or to broaden cultural horizons (Recchi 2005; Favell 2008a).

Free movement has been at the core of the European integration project from the early days, although it was originally intended only for the economically active population (Baldoni 2003). After the signing of the Maastricht Treaty in 1992, which formally introduced the legal concept of a common European citizenship, the right to work and live in any member state was recognized for all EU citizens, irrespective of whether they were economically active or not. As an area currently comprising 28 countries with more than 500 million inhabitants, the European Union can be regarded as an exceptional research laboratory on legal and unrestricted transnational migration (Koikkalainen 2011). However, both research and public debate on migration in Europe have primarily focused on international migration from outside the EU, and less attention has been devoted to intraEuropean migration.

A borderless Europe facilitates the transnationalization of the lives of European citizens. The ease of moving back and forth across countries has fostered permanent settlement as well as temporary, circular and onward migration, changing the

Clara Cortina

clara.cortina@upf.edu

Teresa Castro-Martín

teresa.castro@cchs.csic.es

1 Institute of Economics, Geography and Demography, Center for Human and Social Sciences, CSIC, Madrid, Spain

2 Department of Political and Social Sciences, Universitat Pompeu Fabra, Barcelona, Spain 
traditional patterns of migration. The abolishment of frontiers between European Union member states has also blurred considerably the distinction between international and internal migration (King 2002; King and Skeldon 2010). In general, destinations have diversified, migration projects have become more individualized, and decisions to move to another European country are nowadays driven by a plurality of motives. Although career considerations and the possibility of earning a better salary remain an important motivation to leave the country of origin, non-work reasons for migrating (family, affective relationships, study, retirement or lifestyle considerations) are an important aspect of intra-European migration (Gilmartin and Migge 2013; Santacreu et al. 2009; Verwiebe 2014). This raises new questions on migration decision-making, the importance of origin and destination countries in this decision-making process, and the importance of networks and family relations both before and after the move (Benton and Petrovic 2013; De Winter et al. 2014).

This special issue addresses the topic of intra-European migration from a demographic perspective. Across Europe we find mobility taking place at different times in people's lives: one can find students, working adults and pensioners all in the process of migrating. Being thus embedded in individuals' life trajectory, the decision to migrate and the actual experiences of intra-European migration may be better understood from a life course perspective (de Valk et al. 2011). The life course perspective emphasizes the importance of socio-historical context and geographical location, time, the role of social ties and important others as well as human agency in the shaping of the individual life (Elder 1985). Applying this perspective to the study of intra-European migration, it is possible to gain a more profound understanding of the interplay among different dimensions of the individual life trajectory. First, it may, for example, help in understanding how choices and experiences in the educational and occupational context influence processes of partnership and family formation as well as migration decisions, by linking both the private and public spheres in life, including demographic behaviour. Second, a life course approach also takes into account that individual migration experiences are not taking place in a social vacuum. Consequences of migration are not necessarily limited to migrants themselves but may equally affect the life trajectories of the migrants' non-mobile social network (including intergenerational family and support relations). Finally, life course research studies individuals in their institutional context that shapes and is shaped by individual migration experiences in various ways. Although life course data for intra-EU migrants are still relatively scarce, this special issue features four innovative demographic studies on intra-EU migration. The four articles in this collection address different aspects of the complex, diversified and dynamic phenomenon of intra-EU migration. Specifically, the contributions show (1) the influence of the context, i.e. labour market laws on European migrants' destination choices; (2) the link between family life dynamics and migration trajectories; (3) the impact of cross-national mobility on the formation of European binational couples and (4) the distinctiveness of European migrants' residential patterns.

In the following, we elaborate on the particular nature of unrestricted EU migration, reflect on the available data to study EU migration from a life course 
perspective, and discuss the prevalence and types of EU migration as well as the profile of EU migrants. Furthermore, we briefly review existing demographic studies on EU migration and introduce the contributions of this special issue.

\section{A Brief History of EU Migration}

After World War II, migration patterns in Europe were primarily characterized by emigration to North America, South America and Australia. However, from the 1950s onwards Europe became increasingly popular as a destination for labour and post-colonial migrants. The first large migratory movements from southern European countries to the more industrialized northwestern European countries also began shortly after the Second World War. They were mainly driven by the high demand for labour, especially for lower-skilled employment, in the latter economically more developed countries. Several northwestern European countries, including Germany, Belgium and the Netherlands, had guest worker programmes and agreements with countries in Southern Europe and the Mediterranean to recruit the predominantly male unskilled labourers. Nevertheless, already during this period, migration in Europe was not just limited to South-North migration, as is illustrated by among others the considerable migration movements from Ireland to the UK and from Finland to Sweden. The oil crisis in the early 1970s put a sudden end to the so-called guest worker programmes and labour migration consequently declined sharply. Nevertheless, migration flows from these countries continued but were then mainly taking the form of family reunification. As a result, immigration from the Mediterranean countries (including Turkey and Morocco) continued in the 1980s and an increase in asylum migration from other parts of the world was notable in many European countries starting primarily in the 1990s. During this time, intraEU migration rose only slightly (Hansen 2003; Van Mol and de Valk 2015).

The formal establishment of the Schengen area in the mid-1990s helped to enable the free movement of Europeans by abolishing border controls among a wide range of European countries. However, one should be aware that the Schengen Treaty focuses mainly on facilitating travel. Furthermore, the Schengen zone does not include all EU-28 members states (Bulgaria, Croatia, Cyprus, Ireland, Romania and the United Kingdom are not part), whereas the European Free Trade Association countries (Iceland, Liechtenstein, Norway and Switzerland) are part of the Schengen agreements.

Although successive EU treaties extended the right to free movement within the EU (Recchi 2005), it was not until the incorporation of 12 new member states between 2004 and 2007 (mainly central and eastern European countries) that intraEU migration rose substantially (Favell 2008b). This migration was predominantly from central and eastern European countries to their western neighbours and was motivated by large differences in the labour market opportunities and earnings. These flows were significant, even before the temporary restrictions on labour market access for citizens of the new EU member states were put into effect (Eurostat 2011). Looking at the most important immigration flows in two different time periods (2003-2007 and 2008-2012), we find that between 2003 and 2007, as 
shown in Fig. 1, the largest migration flows were recorded from Poland to Germany, followed by Romanians migrating to Spain and Italy.

The recent period of intra-European migration (2008-2012 in Fig. 1) is marked by a financial and economic crisis and declining labour demand across Europe (hitting certain European countries harder than others). Consequently, migration flows from Eastern to Western Europe in general have decreased considerably, although they seem to have partly bounced back in the most recent years (European Commission 2014a). The increased unemployment rates in many destination countries have also fostered return migration (Zaiceva and Zimmermann 2012). At the same time, a second wave of labour migration has been observed from southern to northern European countries, since countries such as Spain, Portugal and Greece have been affected most severely by the economic and financial crisis (Benton and Petrovic 2013). Due to the combination of increased emigration and declining immigration, the net migration in some southern European countries has turned negative (not in Figure). Figure 1 illustrates, for example, that migration from Romania and Bulgaria to Spain declined considerably between 2008 and 2012 compared with the 2003-2007 period. Although it is unclear why this decrease is not observed for Italy, it might have to do with different labour market structures and restrictions for Romanian workers in Spain versus Italy. In contrast, migration from Spain to the UK increased between 2008 and 2012 compared with the previous 5-year period.

One should be aware that the migration flows as reported above cover people moving for labour- or work-related reasons, but also those who have other incentives for moving. The right of free movement within the EU has opened up a space for multiple forms of mobility. Migration movements of temporary nature, including circular migration, such as retirement and student migration are more important nowadays than they were some decades ago (Warnes and Williams 2006).

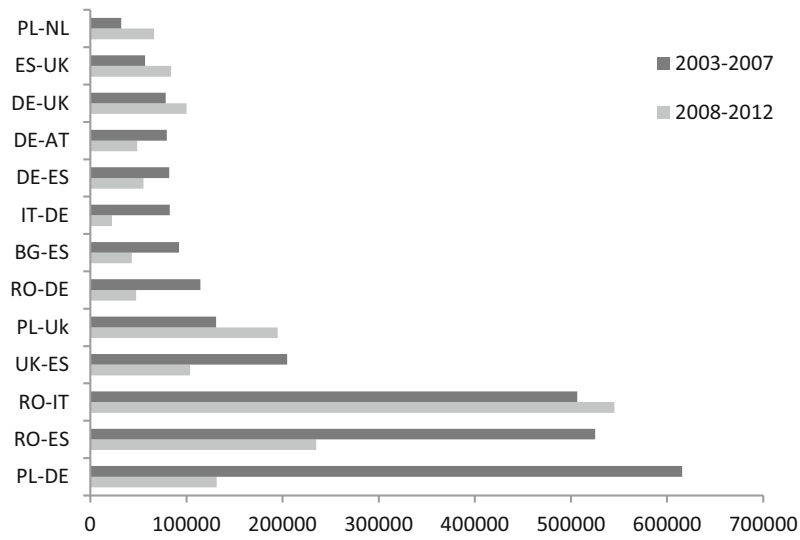

Fig. 1 Major intra-European immigration flows according to country of previous residence, absolute numbers

Source Eurostat 2014 (online data code: migr_imm5prv). AT Austria, BG Bulgaria, DE Germany, ES Spain, IT Italy, $N L$ Netherlands, $P L$ Poland, $R O$ Romania, $U K$ United Kingdom

Note The Eurostat database on immigration is neither complete for all the years of the time period nor for all the destination countries 
A clear example is the North-to-South retirement migration, which has increased considerably in the past decades (King et al. 2000), motivated by among others a higher quality of life and lower costs of living. Some retirees move back and forth seasonally, without formally registering in the new country, making it difficult to obtain accurate data of the total number of pensioners living in multiple EU countries throughout a given year (Gustafson 2008).

Student migration is another type of migration that has become increasingly prevalent in the European Union and is attracting more and more scholarly attention. The European Commission strongly promoted intra-European student mobility with the so-called Erasmus programme, and more than 3 million students have benefitted from this exchange programme since it was launched in 1987. Although student mobility is typically temporary, it is generally assumed that it would promote international labour mobility later in the course of their lives (European Commission 2014b). Nevertheless, there is limited empirical evidence for a causal link between student mobility and increased aspirations towards the international labour market. Van Mol (2014) showed that those who participate in the Erasmus programme are already more inclined towards future geographical labour mobility before participating. At the same time, student migration is more and more common and a clear example of how intra-European migration is already experienced at an early stage in the life course.

In fact, data from the Eurobarometer 398, collected in 2013 (European Commission 2013), indicate that $9 \%$ of EU citizens have had the experience of living and working in another EU country at some point in their lives. According to this survey, those who are most likely to have lived and worked in another EU member state are mainly men, young adults aged 25-39 and highly educated persons. Among those who had not lived abroad, language proficiency and family ties were reported as the main barriers to mobility.

The prospects for increasing European mobility in the near future are high according to the Eurobarometer. One in four EU citizens states that they would definitely or probably consider working in an EU member state other than their home country within the next 10 years. There is, however, substantial variation across societies in the share of people considering working in another EU country, ranging from $12 \%$ in Austria to $54 \%$ in Sweden (European Commission 2013).

\section{Data on Intra-European Migration and Migrants}

Despite the aforementioned patterns of migration, getting data-driven insight into intra-European migration flows is not a simple matter. This has partly to do with the availability and reliability of migration statistics in general but is also related to the specific case of intra-European migration. The absence of border controls and requirements of visa and work permits make it in principle simple for European citizens to cross-national borders and settle in another country. Consequently, many of these moves remain invisible in official migration data and therefore limit the current possibilities to accurately approximate the volume and patterns of intra-EU migration flows. 
Furthermore, migration statistics in general do have their problems and vary considerably regarding availability, reliability and comparability. Despite a range of projects aiming at improving migration statistics, their coverage and consistency (see, e.g. Raymer et al. 2012), they still have important limitations one should be aware of when studying intra-European migration. As we have seen in Fig. 1, not all European countries provide Eurostat with continuous series of immigration by previous country of residence, which clearly limits the possibility of measuring intra-European migration for the whole EU. Furthermore, when trying to complete the restrictions of immigration data from receiving countries with emigration statistics from sending countries, clear and well-documented discrepancies appear (Poulain et al. 2006). In addition, countries differ to the extent that they record emigration and movements of their own nationals, which limits capturing all flows (including those of return migrants) (de Beer et al. 2010). Furthermore, most national data collection systems are not designed to adequately capture short-term mobility for study or seasonal work, circular migration or cross-border commuting. Many EU citizens that move to another member state for a short period without plans to settle permanently do not tend to register as residents; hence, both stock and flow data are likely to underestimate the true extent of migration within Europe.

\section{Number and Distribution Patterns of EU Migrants}

Although EU citizens have the right to live, work, study and retire anywhere in the Union, on 1 January 2013, only $2.8 \%$ of Europeans resided in an EU country other than their country of citizenship (Eurostat Statistics Database 2014), even though this is a potential underestimation of the actual numbers, given the data limitations mentioned before. Nonetheless, the absolute number of Europeans living in another EU country has increased substantially since 1990: from about 5.5 to 13.7 million. European citizens currently represent $40 \%$ of the total migrant population in the EU. Intra-European migrants comprise an important share of the population in many European countries, often accounting for half of all migrants in the country (based on citizenship), and in some countries such as Luxemburg, Cyprus, Ireland, Malta, Belgium or Netherlands they even outnumber non-EU foreign citizens (Fig. 2).

Since migrant stock can be defined based on nationality of the person as well as on country of birth, it is worthwhile to also have a look at the data based on country of birth. When we consider data on migrants' country of birth (instead of citizenship), absolute figures change but patterns remain similar. In 2013, 17.3 million Europeans lived in a member state other than the one where they were born in, accounting for $3.5 \%$ of the total EU population and for $34 \%$ of the total migrant population in the EU (Eurostat Statistics Database 2014). The differences observed in the numbers based on citizenship and country of birth are largely due to naturalization. The fact that data do not differ much between citizenship and country of birth for the European migrant stock relates to the fact that changes of nationality are relatively rare among Europeans. In 2012, only $11 \%$ of those adopting a new EU citizenship were citizens of another member state (Eurostat Statistics Database 2014). 


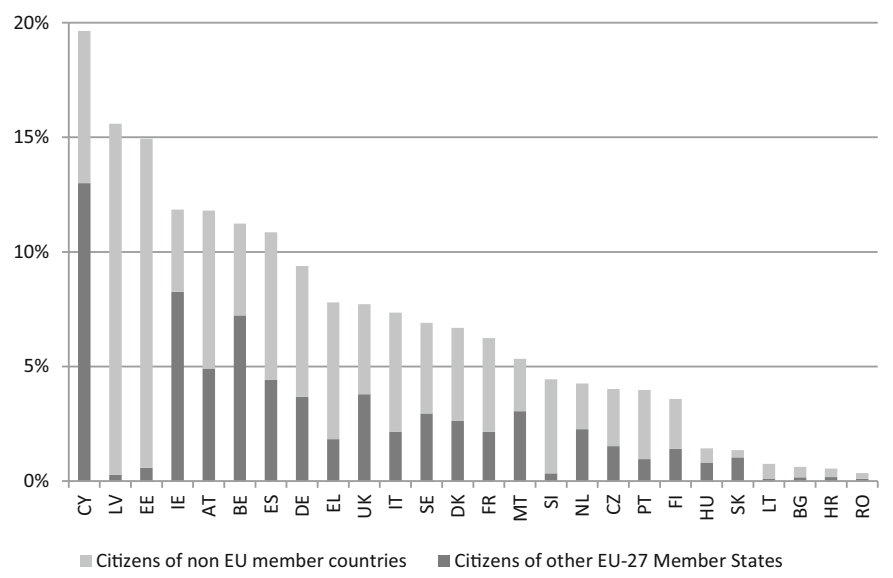

Fig. 2 Share of non-nationals in a country's resident population, 1 January $2013(\%)$ Source Eurostat 2014 (online data code: migr_pop1ctz). CY Cyprus, LV Latvia, EE Estonia, IE Ireland, $A T$ Austria, BE Belgium, ES Spain, DE Germany, EL Greece, UK United Kingdom, IT Italy, SE Sweden, DK Denmark, FR France, MT Malta, SI Slovenia, NL Netherlands, CZ Czech Rep., PT Portugal, FI Finland, $H U$ Hungary, $S K$ Slovakia, $L T$ Lithuania, $B G$ Bulgaria, $H R$ Croatia, $R O$ Romania

Note Luxembourg is not included in the graph, but its share of non-nationals is the highest in Europe with $38.4 \%$ of citizens of other EU-27 countries and $6.1 \%$ of non-EU countries

The origin and spatial distribution of intra-EU migrants across Europe is far from balanced. In 2013, half of all intra-EU migrants (EU citizens residing in a different EU country) were from the new member states that joined the EU since 2004, although these countries currently account for only $21 \%$ of the total EU population (Eurostat Statistics Database 2014). The largest numbers of EU citizens that lived in another EU country in 2013 were from Romania (2.3 million), Poland (1.8 million) and Italy (1.1 million). The top five countries of destination were Germany, Spain, the United Kingdom, France and Italy. Some of the main destination countries have received large numbers of intra-EU migrants from a single country of origin. For instance, over three quarters $(75 \%)$ of Romanian citizens living in another EU country are in Italy or Spain, and over two-thirds (68\%) of Polish citizens living in another EU country are in the United Kingdom or Germany.

So far we have mainly focused on migrants and have not included their children. However, it is relevant when we discuss demographic issues of European migration to also cover the children that are born of European migrant parents (second generation). As shown in Fig. 3, the population born in the country of residence with at least one foreign-born parent in $2008^{1}$ was between 3 and $6 \%$ of the total working-age population in many western European countries. Interestingly enough, the origin of this second generation is largely European (either one or both parents were born in another EU member state) in countries such as France, Belgium,

\footnotetext{
1 We present data for 2008 because comparative data on parents' country of birth are available in the ad hoc module Labour market situation of migrants and their immediate descendants of the EU Labor Force Survey 2008. A similar ad hoc module was included in the EU-LFS 2014, but data are not available yet.
} 


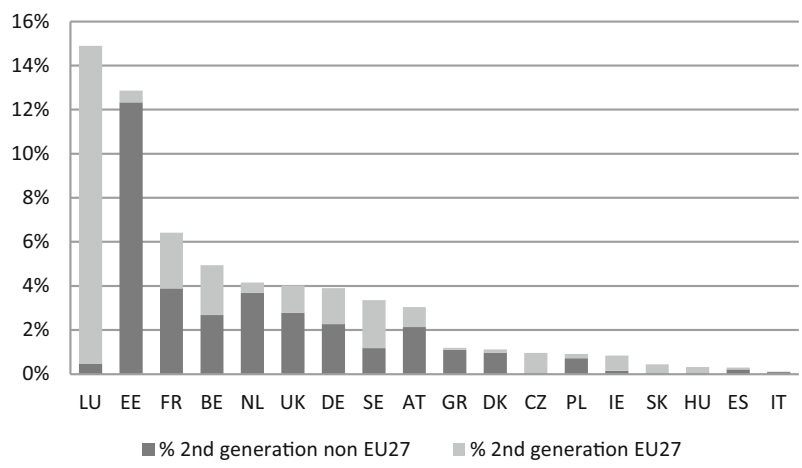

Fig. 3 Share of the second generation of immigrant origin in the resident population aged 15-64, by parents' country of birth, $2008(\%)$

Source Eurostat, 2008 Labour Force Survey ad hoc module on the labour market situation of migrants and their immediate descendants (online data code: fso_08cobsmf)

Legend See Fig. 2

Note Countries with missing information on parents' country of birth have not been included

Germany or Sweden, reflecting the traces of the intense European migration flows already taking place during the 1950 s and 1960s.

\section{Socio-Demographic Profile of EU Migrants}

Intra-European migrants are a heterogeneous population due to their diverse motives of migration and the very different histories of migration between some countries in Europe. Recent research has documented that migration processes within Europe are the result of complex decision-making processes in which not only economic factors, but also social network resources and a variety of social, familial and cultural factors play important roles (Gilmartin and Migge 2013; Verwiebe 2014). This large diversity of migrant profiles in the EU-15, including traditional low-skilled economic migrants, highly educated young professionals, retirement migrants, students, lifestyle movers and binational family members was also documented by the PIONEUR project. The same study also found that crossnational marriages and personal relations were a prominent motive for moving within the EU-15 (Recchi and Favell 2009).

According to a recent study of the European Commission (2014a), among all the EU citizens residing in another EU country in 2012, more than three quarters-over 10 million-were of working age. On average, their employment rates were higher than those of nationals, but their labour market situation varied considerably depending on country of residence and country of origin. In general, EU migrants from Western European origin tend to be young and highly educated, and their migration decisions are often driven by ambitions regarding career development, although for some, family, relationship and lifestyle considerations are also relevant motives (Recchi 2008). In contrast, the majority of EU migrants from Eastern 
European countries moving to Western Europe have medium level education and tend to be employed in low-skilled jobs below their qualification and in temporary contracts (Kahanec 2013). The motives of their decision to migrate and their work trajectories upon migration thus resemble the traditional labour market migration flows of the 1950s and 1960s from Southern Europe to Western Europe.

\section{A Demographic Perspective on EU Migration}

Research on intra-EU migration has largely focused on its economic impact on the receiving countries (Galgóczi et al. 2009). The demographic features and implications of intra-EU mobility are still under-researched. Although migration is the major factor contributing to contemporary population change in Europe, research including demographic studies, have given more attention to international migration from outside Europe than within Europe. One explanation for the lack of interest in intra-EU migration is the policy context in which most of the focus is on integrating migrants from culturally distinct countries. A large number of studies in the migration literature have taken this integration perspective, seeing it as key for maintaining social cohesion in society. This is reflected in policy at the national level as well as at the European level: mobility within the EU has been actively supported and is perceived to be a positive aspect of European integration by the European Commission (European Commission 2014c), whereas the conditions for migration from non-EU countries have become more restrictive (Verwiebe et al. 2014). Studying EU migrants may thus be seen to be less necessary or an important policy issue, since barriers for moving are perceived to be limited and migration is mainly seen as a positive experience for the individual. Furthermore, in demographic migration studies the importance of population ageing has been key. Whereas international migration has repeatedly been discussed as a solution for population ageing, intra-European migration has a limited scope of solutions for slowing down the process of population ageing because most EU countries have fertility rates below replacement and are confronted with similar ageing prospects (van Nimwegen and van der Erf 2010). Yet, intra-European migration plays an increasingly important role in solving labour market shortages related to population ageing and workforce decline. More affluent countries and regions are likely to benefit from the inflow of young EU citizens of working age. However, as the main sending countries in Eastern and Southern Europe are precisely the ones with the lowest fertility rates, East-West and South-North migration flows may accelerate population ageing and decline in those regions, increasing regional disparities and demographic imbalances within Europe. These processes actually demand more indepth study of intra-European migrants and their characteristics over time. Even though intra-EU migration is expected to be of a temporary nature, the question is still open as to how many migrants - and who, exactly-will end up returning to their home countries. The demographic impact of migration flows for both sending and receiving countries might ultimately depend on the number and demographic characteristics of migrants. The life course perspective is needed here to understand how migration relates to career development, union and family formation, 
intergenerational (care) relations and the well-being of the individual and the family.

These issues have been partially studied for non-EU migrants. Studies have covered education, employment, health, family formation and residential trajectories of non-EU migrants in a large number of European societies. It is being more widely acknowledged that a life course perspective is useful for understanding the interdependence between demographic events and migration (Kulu and Milewski 2007; Wingens et al. 2011). However, so far, often only separate transitions or spheres among the largest immigrant groups from outside the EU are covered, whereas an explicit focus on intra-European migrants is rarely adopted (Kulu and González-Ferrer 2014).

Two domains that have received ample attention in demographic studies of immigrants are fertility and family dynamics. First, immigrant fertility has attracted considerable research interest, not only because of its potential impact on current and future fertility trends and old age dependency ratios in the country of reception, but also because childbearing patterns are considered to be a key indicator of immigrants' degree of integration in the host society (Adserà 2014). Such studies find a gradual convergence towards the fertility level of the host society in the first generation (Sobotka 2008) and small differentials in the second generation (Scott and Stanfors 2011; de Valk and Milewski 2011). However, intra-EU migration presents the unusual opportunity to study fertility change in the reverse direction, i.e. whether the process of convergence is also observed among migrants originating from very low fertility countries in Eastern or Southern Europe that move to a higher fertility country within Europe (Waller et al. 2014; Lübke 2015 on Polish immigrants in the UK). This would allow for an assessment of whether and how changes in economic, social, cultural and policy environment result in different fertility norms and behaviour.

Second, studies on migrants' family dynamics find that socialization factors and cultural background play an important role in explaining native-immigrant differentials in union formation and dissolution (Kulu and González-Ferrer 2014; Huschek et al. 2012). Again, these studies focus largely on migrants from outside the EU (Hannemann et al. 2014). Particular attention has also been given to the patterns of intermarriage, generally considered both as an indicator and a catalyst of successful integration (Kalmijn and van Tubergen 2006), and to the stability of mixed marriages (Milewski and Kulu 2014) in the European context, but few studies distinguish between immigrants of European and non-European origin, and crossnational comparisons are scarce. The recent studies (derived from the EUMARR project) that specifically addressed intermarriage patterns and trends across different EU countries are a noteworthy exception to this trend (de Valk and Díez Medrano 2014). This project analysed the trends in European binational marriages over time in order to assess whether the increasing transnational mobility of European citizens has led to an increase in social and family ties among them. Contrary to initial expectations, the findings showed that the number of binational marriages between Europeans remains relatively small, not having increased in the past 20 years. Only for Spain, which has received large-scale migration flows from Romania since 2003, was a significant increase in the incidence of European binational marriages found, 
primarily caused by Spanish men marrying Eastern European women (Díez Medrano et al. 2014).

\section{Contribution of this Volume: Destinations, Family and Settlement}

In light of the increased prevalence of European migration and migrants in European societies, it is crucial to include this topic in future demographic studies. This special issue is an attempt to encourage this line of research by bringing together studies that focus on the growing share of European migrants. The four contributions cover different periods within the individual life course and address important aspects of the demographic behaviour of European migrants, such as their choice of destination, their linked family and migration trajectories, and their settlement conditions. Each of the contributions brings up relevant and key research questions for understanding intra-EU migration and the individual consequences of the moves, including the impact of family bonds in the destination country on return migration, the potential effect of mobility on fostering marriages between Europeans of different countries or the suitability of studying residential concentration for European migrants. Overall, they provide an excellent illustration of the different issues, approaches, data and methodologies that can be used to advance our understanding of intra-EU migration. The types of data sources used in the four studies range from aggregate flow statistics, population registers, surveys and census data on small areas. Their advantages and limitations illustrate that various complementary data collection strategies are needed to capture intra-EU migration flows and intra-EU migrants' life trajectories (Kleinepier et al., in this issue).

The contribution by Palmer and Pytlikova focuses on migration flows following the eastward enlargement of the European Union. It advances our understanding of migrants' decisions in a scenario of multiple potential destination countries. Using annual data on migration flows and stocks organized by origin-destination pairs as well as information on legal regimes, and controlling for a set of economic, social, cultural and geographical variables in sending and destination countries, the study examines the influence of labour market laws on the magnitude and composition of intra-European migration flows. In the 2004 and 2007 enlargement processes, citizens from eastern European countries gained the right to travel and reside in any other EU country, but many potential destination countries imposed temporary restrictions on their employment. The combination of freedom of movement and restrictions on access to formal employment, which differ by country as well as over time, allows the authors to test whether migrants from new EU member states were attracted to old member states with less restrictive labour market regulations. The results of the analysis confirm that destinations that granted migrants greater access to the formal labour market received larger flows of migrants from Eastern Europe, but they also show that the importance of labour market access on migrant flows is mediated by social networks, language ability and educational level. Although labour market conditions in destination countries play an important role in migrants' decisions, migration is also closely interconnected to the family life course (Bailey and Boyle 2004). 
The links between family and migration behaviour are the focus of the contribution by Kleinepier, de Valk and van Gaalen, who study Polish migration to the Netherlands, the largest migration flow to this country over the past decade. The period analysed consists of the years after Poland became a member of the EU but during which a work permit was still required for labour migrants. Using longitudinal population register data, the authors reconstruct the family and migration trajectories of young adult Polish migrants in the Netherlands during a period of 5 years after the initial migration move. Applying sequence analysis, the study describes the predominant family and migration trajectories and analyses the factors that select migrants in typical life paths. Given that a considerable share of Polish migration is of temporary and circular nature, special attention is drawn to work circumstances and family transitions that influence return migration. The results reveal that unemployment increases the probability of return migration, but that partnership and fertility transitions matter just as much. More specifically, having a Dutch partner or having children in the Netherlands significantly decrease the likelihood of return migration. The study also finds significant gender differences: men are more likely to remain single and return to Poland, while women are more likely to enter into a partnership and stay in the Netherlands. This article provides an excellent illustration of the potential of analysing family and migration behaviour jointly and from a longitudinal perspective and corroborates the idea that migration decisions are better understood when taking the family dimension into consideration.

The links between migration and family behaviour are also addressed in the contribution by Schroedter, De Winter and Koelet, which focuses on the influence that cross-national mobility earlier in life may have on the formation of European binational couples. Applying a broad life course perspective, the authors examine to what extent mobility experiences during childhood and early adulthood influence the choice of a partner from a different European country. The analyses rely on data from a survey conducted in 2012 in the context of the EUMARR project in cities in Belgium, the Netherlands and Switzerland. The results confirm that intra-European mobility experiences during early adulthood (both short and long stays abroad) are associated with higher intermarriage rates for this population. Intra-European mobility, hence, is essential in fostering the formation of European binational couples and culturally blended families, which may strengthen transEuropean social ties and, in the long term, enhance social cohesion within Europe.

The fourth contribution, by Sabater, examines whether the residential patterns of recent intra-EU immigrants in the UK exhibit signs of socio-spatial exclusion comparing different cohorts of migrants. Immigrants' levels of residential segregation are known to shape their patterns of daily social interactions and thus may condition the pace of adaptation and integration in the host society. Mobile EU citizens are presumed to have few integration needs, as they are often regarded as temporary residents enjoying the same rights as natives do. However, they may face similar barriers to the hosting society as non-EU migrants, such as insufficient language proficiency, difficulties to access local social networks and housing, as well as spatial concentration in disadvantaged neighbourhoods (Kennedy 2008; Collett 2013; Van Mol and Michielsen 2014). The study by Sabater assesses 
whether the traditional pattern of residential concentration in ethnically similar neighbourhoods upon arrival being followed by dispersal towards areas with better living conditions also applies to migrants from Eastern and Southern Europe. Using data from the 2011 UK census and a comprehensive geo-demographic classification of small areas, the author describes the main socio-spatial characteristics of the neighbourhoods where immigrants from Poland, Spain, Italy and Portugal live. The results show that immigrants predominantly settle in urban areas upon arrival. Compared with former migrants with very clustered residential patterns, recent migrants exhibit more spatial dispersion in their residence choices. There are, however, important differences across immigrant groups: Spanish and Italian migrants are more widely dispersed across neighbourhood types than their counterparts from Portugal and Poland. In addition, Polish immigrants are overrepresented among migrants living in disadvantaged neighbourhoods. Overall, this study illustrates the potential of socio-spatial analysis to understand the interrelationship between residential choices and social exclusion or inclusion of intra-EU migrants.

This special issue offers a snapshot of recent research on intra-EU migration from a demographic perspective, shedding light on intra-EU migrants' destination choices, odds of return migration, intermarriage and residential patterns. In this regard, the life course framework, which stresses the importance of the timing, sequencing and interdependencies of different life transitions, serves as a valuable theoretical guideline for studying mobility decisions, the life trajectories before and after migration, the family dynamics, and the integration processes of intra-EU migrants and their descendants (de Valk et al. 2011). A migration move within the EU is probably less disruptive on the life course than is the case for other international migration moves because legal obstacles have been removed and intraEU migrants enjoy similar rights as natives in the countries of settlement. Nevertheless, the move constitutes a key life transition that will shape migrants' life trajectories in multiple domains, including work, partnership formation, childbearing, social networks and further migration paths. In the context of ageing European societies, it is crucial to know more on how these moves affect intergenerational care relations, particularly for parents left behind. It may impact relations between parents and young children to an equal extent. It has been suggested that some migrants leave their young children behind when moving across Europe. The effect the separation might have on the well-being of both parents and children has yet to be addressed. At the same time, those European migrants who do have children in the country of destination still face the challenges of an educational system with which they are not familiar. In this regard, similar issues may come up as have been reported for non-European children of immigrants, including language barriers, lack of knowledge about the system or tracking into lower educational tracks, all potentially resulting in lower educational outcomes for these children.

The demographic implications of young adults' intra-EU mobility for sending countries have so far largely been neglected. However, especially in a potentially highly dynamic migration context such as the EU, ignoring the country of origin perspective is extremely problematic (for more details, see the newly started Mobile Welfare project). Furthermore, the second generation's own transnational 
movements and links as well as family behaviour also have yet to be studied. The studies in this special issue are a first attempt in this regard but need to be replicated in other countries in order to ascertain whether findings can be generalized across countries and groups. Comparative research in a borderless Europe is particularly promising, as it offers a unique opportunity to explore how the family domain and the socio-economic context in multiple sending and receiving countries shape the drivers, constraints and patterns of migration when there are no legal barriers. This last issue is especially relevant in and of itself: the extent to which EU legal distinctions between categories of migrants and associated rights are leading to new inequalities in the life trajectories of intra-EU and non-EU migrants and thus have an impact on social cohesion at large is significant for both researchers and society at large.

The broad transformation brought about by the process of economic, social and political European integration, as well as the relatively recent context of free mobility, has modified many features of migration which have not yet been examined. Whereas migration has traditionally been studied as a single move to a new country, contemporary intra-EU migration is often multidirectional, temporary or circular. These multiple moves of the individual and the family may have important consequences for the person in terms of social relations and well-being. In particular, the effects of high levels of mobility for the later life outcomes of children are still to be understood.

Migration studies have also drawn attention to various aspects of structural integration and social inclusion, such as the spatial settlement of migrants in the host country. Previous research has mainly focused on the ethnic dimension of the phenomenon (Bolt 2009), which is often more salient for migrant groups from outside the EU. However, recent studies have shown for the case of Spain that the intensity of residential segregation of eastern European migrants (mainly Rumanians and Bulgarians) in large Spanish cities is similar to that of migrants that arrived in the same period from other parts of the world (Sabater et al. 2012).

The wide variety of reasons for migration results in a highly heterogeneous profile of intra-EU migrants and their demographic behaviour. Compared with immigration waves from outside Europe, which involve visa and work permits, the free movements of Europeans across borders is also often more difficult to capture in data. These features of intra-European migration challenge studies on mobility within Europe. At the same time, given the importance of migration for European populations both now and in the future, demographic studies should pay extra attention to it in all its complexity. A life course perspective on intra-EU migration will increase our understanding of the dynamics of past, present and future migration flows within the European Union and their consequences. This special issue illustrates the fruitfulness of studying intra-EU migration from a life course perspective and provides valuable insights that can be the point of departure for further studies of key interest to not only demographers, but also scholars from adjacent disciplines, as well as policy makers.

Acknowledgments We would like to express our gratitude to the reviewers that provided generous and helpful feedback to the manuscripts in this special issue. Their insightful comments and suggestions were 
of great value for the authors in the revision of their contributions. We would also like to sincerely thank Helga de Valk, Nicole Hiekel and Christof Van Mol for providing valuable guidance and thoughtful advice on the introduction to this special issue.

\section{References}

Adserà, A., \& Ferrer. A. (2014). Immigrants and demography: Marriage, divorce, and fertility. IZA Discussion Paper Series No. 7982. Bonn: Institute for the Study of Labor.

Bailey, A., \& Boyle, P. (2004). Untying and retying family migration in the new Europe. Journal of Ethnic and Migration Studies, 30(2), 229-241.

Baldoni, E. (2003). The free movement of persons in the European union: A legal-historical overview. State of the art report. PIONEUR Working Paper No. 2.

Benton, M., \& Petrovic, M. (2013). How free is free move-ment? Dynamics and drivers of mobility within the European union. Brussels: Migration Policy Institute Europe.

Bolt, G. (2009). Combating residential segregation of ethnic minorities in European cities. Journal of Housing and the Built Environment, 24(4), 397-405.

Collett, E. (2013). The integration needs of mobile EU citizens Impediments and opportunities. Resource document. Migration policy institute Europe. http://www.migrationpolicy.org/pubs/MPIEuropeFreeMovement-Integration.pdf

de Beer, J., Raymer, J., van der Erf, R., \& van Wissen, L. (2010). Overcoming the problems of inconsistent international migration data: A new method applied to flows in Europe. European Journal of Population, 26(4), 459-481.

de Valk, H. A. G., \& Díez Medrano, J. (2014). Guest editorial on meeting and mating across borders: Union formation in the European Union single market. Journal of Population, Space and Place, 20(2), 103-109.

de Valk, H. A. G., \& Milewski, N. (2011). Family life transitions among children of immigrants: An introduction. Advances in Life Course Research, 16(4), 145-151.

de Valk, H. A. G., Windzio, M., Wingens, M., \& Aybek, C. (2011). Immigrant settlement and the life course: An exchange of research perspectives and outlook for the future. In M. Wingens, M. Windzio, H. A. G. de Valk, \& C. Aybek (Eds.), A life-course perspective on migration and integration (pp. 283-297). Dordrecht: Springer.

De Winter, T., Koelet, S., \& de Valk, H. A. G. (2014). Intergenerational contact in European transnational families: A case study of Belgium. Paper presented at the European Population Conference, Budapest, June 25-28, 2014.

Díez Medrano, J., Cortina, C., Safranoff, A., \& Castro-Martín, T. (2014). Euromarriages in Spain: Recent trends and patterns in the context of European integration. Journal of Population Space and Place, 20(2), 157-176.

Elder, G. H. (1985). Perspectives on the life course. In H. Glen \& G. H. Elder (Eds.), Life course dynamics: Trajectories and transitions 1968-1980 (pp. 23-49). Ithaca: Cornell University Press.

EUMARR Project (2010-2013). Towards a European society: Single market, bi-national marriages and social group formation in Europe. European Science Foundation. http://www.ibei.org/projects/ eumarr

European Commission (2013). Eurobarometer on the internal market. Resource document. Brussels: DG Communication. http://ec.europa.eu/public_opinion/archives/ebs/ebs_398_en.pdf

European Commission (2014a). Recent trends in the geographical mobility of workers in the EU. EU employment and social situation quarterly review, Supplement June 2014.

European Commission (2014b). The Erasmus impact study: Effects of mobility on the skills and employability of students and the internationalisation of higher education institutions. Resource document. Luxembourg: Publications Office of the European Union. http://bit.ly/1sP5JtM

European Commission (2014c). European Commission upholds free movement of people. Memo 14/9, 15-01-2014. Resource document. http://europa.eu/rapid/press-release_MEMO-14-9_en.htm

Eurostat. (2011). Migrants in Europe-A statistical portrait of the first and second generation. Luxembourg: Publications Office of the European Union.

Eurostat Statistics Database. (2014). http://ec.europa.eu/eurostat/data/database.

Favell, A. (2008a). Eurostars and eurocities: Free movement and mobility in an integrating Europe. Oxford: Blackwell. 
Favell, A. (2008b). The new face of East-West migration in Europe. Journal of Ethnic and Migration Studies, 34(5), 701-716.

Galgóczi, B., Leschke, J., \& Watt, A. (Eds.) (2009). EU labour migration since enlargement: Trends, impacts and policies. London: Ashgate.

Gilmartin, M., \& Migge, B. (2013). European migrants in Ireland: Pathways to integration. European urban and regional studies. Published online before print. doi:10.1177/0969776412474583

Gustafson, P. (2008). Transnationalism in retirement migration: The case of North European retirees in Spain. Ethnic and Racial Studies, 31(3), 451-475.

Hannemann, T., Kulu, H., González-Ferrer, A., Pailhé, A., Rahnu, L., \& Puur, A. (2014). A comparative study on partnership dynamics among immigrants and their descendants. Resource document. Families And Societies Working Paper 14. http://www.FamiliesAndSocieties.eu/wp-content/ uploads/2014/08/WP14HannemannEtA12014_2.pdf

Hansen, R. (2003). Migration to Europe since 1945: Its history and its lessons. The Political Quarterly, 74(s1), 25-38.

Huschek, D., de Valk, H. A. G., \& Liefbroer, A. C. (2012). Partner choice patterns among the descendants of Turkish immigrants in Europe. European Journal of Population, 28(3), 241-268.

Kahanec, M. (2013). Skilled labor flows: Lessons from the European Union. Social Protection and Labor Discussion Paper no. SP 1301. Washington DC: World Bank.

Kalmijn, M., \& van Tubergen, F. (2006). Ethnic intermarriage in the Netherlands: Confirmations and refutations of accepted insights. European Journal of Population, 22(4), 371-397.

Kennedy, P. (2008). The construction of trans-social European networks and the neutralisation of borders: Skilled EU migrants in Manchester-Reconstituting social and national belonging. Space and Polity, 12(1), 119-133.

King, R. (2002). Towards a new map of European migration. International Journal of Population Geography, 8(2), 89-106.

King, R., \& Skeldon, R. (2010). 'Mind the gap!' Integrating approaches to internal and international migration. Journal of Ethnic and Migration Studies, 36(10), 1619-1646.

King, R., Warnes, A. M., Warnes, T., \& Williams, A. (2000). Sunset lives: British retirement migration to the Mediterranean. Oxford: Berg.

Koikkalainen, S. (2011). Free movement in Europe: Past and present. Resource document. MPI migration information source. http://migrationinformation.org/Feature/display.cfm?ID=836

Kulu, H., \& González-Ferrer, A. (2014). Family dynamics among immigrants and their descendants in Europe: Current research and opportunities. European Journal of Population, 30, 411-435.

Kulu, H., \& Milewski, N. (2007). Family change and migration in the life course: An introduction. Demographic Research, 17-19, 567-590.

Lübke, C. (2015). How migration affects the timing of childbearing: The transition to a first birth among polish women in Britain. European Journal of Population, 31(1), 1-20.

Milewski, N., \& Kulu, H. (2014). Mixed marriages in Germany: A high risk of divorce for immigrantnative couples. European Journal of Population, 30(1), 89-113.

Mobile Welfare project (2014-2017). European welfare systems in times of mobility. www. mobilewelfare.org

PIONEUR project (2003-2006). Pioneers of Europe's integration "from below": Mobility and the emergence of European identity among national and foreign citizens in the EU. European Commission Fifth Framework Programme. http://www.obets.ua.es/pioneur/

Poulain, M., Perrin, N., \& Singleton, A. (Eds.). (2006). THESIM: Towards harmonized European statistics on international migration. Louvain-la-Neuve, Belgium: UCL Presses Universitaires de Louvain.

Raymer, J., Forster, J.J., Smith, P. W. F, Bijak, J., \& Wiśniowski, A. (2012). Integrated modelling of European migration: Background, specification and results. NORFACE Migration Discussion Paper No. 2012-04

Recchi, E. (2005). Migrants and Europeans: An outline of the free movement of persons in the EU. AMID Working Paper Series 38/2005. Aalborg: The Academy for Migration Studies in Denmark, Aalborg University.

Recchi, E. (2008). Cross-state mobility in the EU: Trends, puzzles and consequences. European Societies, 10(2), 197-224.

Recchi, E., \& Favell, A. (2009). Pioneers of European integration: Citizenship and mobility in the EU. Cheltenham: Edward Elgar. 
Sabater, A., Bayona, J., \& Domingo, A. (2012). Internal migration and residential patterns across Spain after unprecedented international migration. In L. Finney \& G. Catney (Eds.), Minority internal migration in Europe. Surrey: Ashgate Ed.

Santacreu, O., Baldoni, E., \& Albert, M. C. (2009). Deciding to move: Migration projects in an integrating Europe. In E. Recchi \& A. Favell (Eds.), Pioneers of European integration. Citizenship and mobility in the EU (pp. 52-71). Cheltenham \& Northampton: Edward Elgar.

Scott, K., \& Stanfors, M. (2011). The transition to parenthood among the second generation: Evidence from Sweden, 1990-2005. Advances in Life Course Research, 16(4), 190-204.

Sobotka, T. (2008). Overview chapter 7: The rising importance of migrants for childbearing in Europe. Demographic Research, 19(9), 225-248.

Van Mol, C. (2014). Erasmus student mobility as a gateway to the international labour market? In J. Gerhards, S. Hans, \& S. Carlson (Eds.), Globalisierung, Bildung und grenzüberschreitende Mobilität (pp. 295-314). Wiesbaden: VS Verlag für Sozialwissenschaften/Springer Fachmedien.

Van Mol, C., \& de Valk, H. A. G. (2015). Migrants and immigrants in Europe: A historical and demographic perspective. In R. Penninx \& B. Garces-Mascareñas (Eds.), Integration as a threeway-process? Integration processes and policies in Europe. Dordrecht: Springer.

Van Mol, C., \& Michielsen, J. (2014). The reconstruction of a social network abroad. An analysis of the interaction patterns of Erasmus students. Mobilities, 1-22. doi:10.1080/17450101.2013.874837.

van Nimwegen, N., \& van der Erf, R. (2010). Europe at the crossroads: Demographic challenges and international migration. Journal of Ethnic and Migration Studies, 36(9), 1359-1379.

Verwiebe, R. (2014). Why do Europeans migrate to Berlin? Social-structural differences for Italian, British, French and Polish nationals in the period between 1980 and 2002. International Migration, 52(4), 209-230.

Verwiebe, R., Wiesböck, L., \& Teitzer, R. (2014). New forms of intra-European migration, labour market dynamics and social inequality in Europe. Migration Letters, 11(2), 125-136.

Waller, L., Berrington, A., \& Raymer, J. (2014). New insights into the fertility patterns of recent Polish migrants in the United Kingdom. Journal of Population Research, 31(2), 131-150.

Warnes, A. M., \& Williams, A. (2006). Older migrants in Europe: A new focus for migration studies. Journal of Ethnic and Migration Studies, 32(8), 1257-1281.

Wingens, M. Windzio, de Valk, H. A. G., \& Aybek, C. (Eds.). (2011). A life-course perspective on migration and integration. Dordrecht: Springer.

Zaiceva, A., \& Zimmermann, K. F. (2012). Returning home at times of trouble? Return migration of EU enlargement migrants during the crisis. IZA Discussion Paper No. 7111. http://ftp.iza.org/dp7111. pdf 